\title{
Eliminating Obstetric Fistula in Muslim Communities
}

\section{Aisha Garba Habib ${ }^{1}$}

\author{
${ }^{1}$ Department of Islamic Studies, Northwest University, Kano- Nigeria
}

\begin{abstract}
There have been assertions that early marriage is the major factor responsible for obstetric fistula in developing countries and some Muslim majority areas. Consequently, some parts of the western world have been agitating for the promulgation of a law that will specify a minimum age of marriage so as to tackle that issue. Islam allows marriage of girls at minority. The paper attempts to discuss the different factors that lead to obstetric fistula and their relationship to early marriage, finding out that early marriage on its own is not a cause but fistula occurs as a result of an interplay of many factors. It finally discusses the measures that should be taken to reduce or even eliminate fistula in developing countries, especially in Muslim majority areas, where early marriage is permitted and practised.
\end{abstract}

\section{Introduction}

In Africa, the child bearing years are the most risky period in the life of women. It has been estimated that at least half a million women die worldwide from pregnancy complications, abortion and childbirth every year. Moreover, the women who get injured because of pregnancy or birth complications outnumber those that die every year (Konje and Ladipo). Among the most serious maternal injuries from childbirth in Africa is Obstetric Fistula. Thus, it is necessary for all stakeholders to exhaust all possible ways of eliminating it for meaningful development.

Of equal importance, is the issue of preserving the moral chastity of the youth in the human society. Islam frowns at sexual permissiveness and all evils, which are likely to bring shame and dishonour to the individual and society. The Qur'an categorically condemns adultery and fornication when it says, "The (unmarried) woman and the (unmarried) man found guilty of sexual intercourse, lash each one of them a hundred lashes..."( Q24:2) But unfortunately, there is no gainsaying in the fact that a major feature of the contemporary society is the rampant cases of illicit sexual relations among the youth. They now engage in all kinds of despicable acts just to satisfy their sexual urge; and that has drastic consequences on the youth and the society at large, as there will never be any meaningful moral development in a society that condones sexual permissiveness. Thus, the only legitimate way of satisfying that urge is for those youth to marry as soon as they start having the urge. However, there are assertions that early marriage causes obstetric fistula. The onus of this work is to investigate this assertion and determine the extent to which it is true.

\section{Marriage in Islam}

Marriage in Islam is an important issue which is highly recommended and in some cases, it is even an obligatory religious duty. It becomes obligatory when there is fear of adultery and fornication or other prohibited acts. The Quran says; "Let those among you who are single marry... and let those who do not find a match keep chaste until Allah makes them free from want out of His grace" (Q24:32-33).

The Prophet (S.A.W) has also said "Marriage is my Sunnah and whosoever abstains from it, is not of me" (Bukhari, 67).

He (S.A.W) also said;

He who is able to marry should marry for it keeps the eye cast down and keeps a man chaste and he who cannot, should take to fasting for it will have a castrating effect upon him" (Bukhari, 5066).

The benefits of marriage are so many. One of the benefits is tranquillity of the mind;

And among His signs is this, that He created for you mates from among yourselves, that you may

This article is published under the terms of the Creative Commons Attribution License 4.0

Author(s) retain the copyright of this article. Publication rights with Alkhaer Publications.

Published at: http://www.ijsciences.com/pub/issue/2015-04/

Article Number: V420150415; Online ISSN: 2305-3925; Print ISSN: 2410-4477 
dwell (live) in tranquillity with them and He has put love and mercy between your hearts..." (Q30:21)).

Another benefit is procreation; "And Allah has made you your mates of your own nature and made for you, out of them sons and daughters and grand children..." (Q16:72)). Mutual love and compassionate are other examples of benefits derivable from marriage.

One important benefit of marriage, which is the concern of this paper is that, it protects an individual from committing adultery as the spouses have been described in the Qur'an as garment to each other; "They (your wives) are garments for you, just as you are garments for them" (Q2:187).

Human beings are created by Allah with certain biological needs, and one of such needs is the sexual desire and satisfaction which naturally begins when an individual reaches puberty. During this period, the urge for sex can be so strong as to even develop into some sort of psychological pressure, which must be satisfied in whatever form possible, either in a halal way or in a haram way. Unfortunately, in most cases, the desire for such satisfaction makes the youngsters deviate from the right path and engage in some unwanted and dangerous actions. Many youngsters resort to fornication, or all kinds of despicable acts in order to satisfy that urge. Vibrators and other sex toys are gaining popularity in the society. Pre-marital sex among secondary school students as well as students of tertiary institutions which often result in teenage pregnancies and abortions altogether add up to the health risks that girls are subjected to. These teenage pregnancies are not limited to the developing countries (as the instinct is universal), but they are also prevalent in the developed countries as well and it has been rising consistently over the years. For instance, the number of teenage pregnancies in England and Wales has risen. The Office for National Statistics data shows that, there were 41.9 conceptions per 1,000 15 to 17 year olds, in 2007. In total, it has been estimated that, there were over 42,900 conceptions in under $18 \mathrm{~s}$. The under 16 conception rates also increased from 7.8 per 1,000 to 8.3 , meaning there were nearly 8,200 pregnancies in just

2007 , (news.bbc.co.uk/2/hi/uk_news/7911684.stm. visited on 9/12/13). A US Government poster on Teen Pregnancy also shows that, over 1100 teenagers give birth every day in the United States alone, and that teenagers account for one in ten new mothers there, (en.wikipedia.org/wiki/Teenage_pregnancy. Visited on $9 / 12 / 13$ ). Thus, marriage which is the only lawful avenue of satisfying that need and preserving the chastity of individuals is the only reasonable alternative to these unwanted acts which teenagers resort to. And that is one of the reasons why Islam allows an individual to marry at whatever age, either minority or majority depending on their personality, discretion and choice.

\subsection{Early Marriage in Islam}

History has shown that, all the divine religions that came before Islam permitted early marriage. For instance, all the peoples of the Book (Christians and Jews) used to marry very young (Abdal Ati, 1982). At various times very youthful marriage prevailed among the Jews; and in the second half of the seventeenth century, the bridegroom was frequently not more than ten years old and the bride was younger. The Roman law stipulated that a man may marry at the age of fourteen and a woman at the age of twelve. This law was adopted by the church and is still preserved in various countries, including some regions of the United States of America (Abdal Ati: 1982).

Islam also allows an individual to marry at an early age if that is what he desires, as it does not peg any particular age as the appropriate time of marriage, since there is no maximum or minimum age limit prescribed by the Qur'an or Hadith. Thus, it is left to people's discretion. The Prophet (S.A.W) married Aisha (R.A) when she was six years old and consummated the marriage when she was nine, while he (S.A.W) gave his own daughter Fatimah (R.A) in marriage to Ali when she was at least 18 years old. Thus, Islam allows an individual to use his discretion and marry at whatever age depending on his personality and choice. However, early marriage is preferred where there is high risk of immorality.

\section{Obstetric Fistulae \\ 3.1 Definition}

The term obstetric fistula is commonly used as an umbrella term to cover vesico-vaginal fistula and its sister ailment recto-vaginal fistula as these fistulae (holes) are caused by trauma suffered during childbirth.

Vesico-Vaginal Fistula is defined by Kabir et al (2006) as,

an abnormal fistulous tract extending between the bladder and

the vagina that allows the continuous involuntary discharge of urine into the vagina vault.

While Recto-Vaginal Fistula (RVF) or stool fistula is defined by Campbell (2001) as, "an abnormal communication between the rectum and the vagina which causes continuous passing of stools through the vagina".

To state it simply, obstetric fistulae, mean holes created between the vaginal wall and the bladder or 
rectum caused by an unrelieved obstructed labour, through which there is continuous leaking of urine or stool that cannot be stopped or controlled by the affected woman. In extreme cases there may even be damage to the nerves of the lower limbs, which may result to the loss of co-ordination in them. Because of the constant leaking of urine or faeces and the accompanying smell, most communities consider such women outcasts and cut them off from all social activities, (Mohammad, 2013).

\subsection{Causes}

Basically speaking, there are two broad causes: surgical procedures and prolonged obstructed labour.

Surgical Procedures: These are of two types: the first which may be termed orthodox medical accidental injury refers to injury caused to the bladder during obstetric operations performed within the formal modern health care system such as the hospital. Such procedures include caesarean sections, difficult forceps delivery and hysterectomy (abdominal or vaginal). In developed world, hysterectomy accounts for $75 \%$ of fistulae. Urological or gastrointestinal pelvic surgery accounts for a small percentage. The second surgical procedures that may lead to obstetric fistula are performed within the traditional healthcare system. These procedures are commonly employed during pregnancy and labour; and lead not only to fistula, but may also cause haemorrhages (blood loss) and sepsis (infection). Examples include the 'Gishiri cut' (a traditional episiotomy) by untrained traditional birth attendants, 'Angurya cut' (a traditional practice in which a tissue is removed from the vagina by traditional surgeons which deliberately narrow the vagina which results to obstructed labour during childbirth), and the insertion of caustic substances into the vagina with the intent to treat a gynaecological condition, (Kabir, et al: 2006).

Prolonged Obstructed Labour: This is the major cause of obstetric fistula in the developing world. Approximately $80 \%$ of fistula cases reported in the developing world including Nigeria are due to unrelieved obstructed labour during childbirth, (Muhammad, 2013)

In a normal delivery, at one time during labour, the bag of water bursts which results to the gushing of fluid from the vagina. At the same time, the expectant mother gets the urge to push. The baby is then, pushed downwards through the birth canal. With each contraction of the uterus, aided by the mother's 'pushing' efforts, the baby's head moves nearer the vulval cleft. The head advances a bit with each contraction, and retreats a bit between contractions, but overall the advance continues, more and more of the head becoming visible. The head stretches the vaginal entrance and the tissues between it and the back-passage (anus). Finally, the forehead appears, followed by the eyes, nose, the mouth and the chin successively. Then the shoulders of the baby and the rest of its body slip out of the birth-canal easily. This stage usually lasts less than one and a half $\left(1 \frac{1}{2}\right)$ hours, extending in time from the full dilatation of the cervix to the birth of the baby, (Jones, 1989, 224).

However, in an obstructed labour, at one time during labour, the advancement of the foetus through the birth canal ceases. This is when the foetal head gets stuck inside the birth canal and is jammed in its maternal pelvis for too long; and if not relieved within three or so hours, the anterior vaginal wall and the bladder become compressed between the foetal skull and the maternal pelvic bone resulting in oedema, necrosis, ischemia (reduced blood flow), slough and eventually a fistula develops. The obstruction may happen as a result of any one of the following:

I. Disparity between the size of the mother's pelvis and foetus that precludes vaginal birth. The foetus may be too big in relation to the mother's pelvis, or the pelvis may be too small for the foetus to pass through the birth canal in a normal vaginal delivery. And this may be as a result of a number of factors to be discussed later.

II. Pelvis Mass: This is in form of a soft tissue that may be located in the pelvis. Fibroids located in the lower segment or on the cervix can prevent descent of the foetal head, causing obstructed labour. Ovarian tumours or rare tumours of the bony pelvis may also prevent the head from entering the pelvis.

III. Persistent and deep transverse arrest: This also can cause an obstructed labour, when the foetus is lying in a wrong position, for example when it is lying across the uterus so it cannot be delivered head first as in normal delivery.

IV. Malpresentation: Vaginal birth is impossible in cases of shoulder or brow presentation.

V. Foetal abnormalities: Abnomalities of the foetus resulting in disparity between the size of the foetus and the pelvis of the mother may also cause obstruction, for example, conjoined twins or locked twins, (www.nursing-help.com/2011/03- visited on 2/12/2013).

Looking critically at all the causes of obstructed labour mentioned above, all of them except the first one, that is, from number two (II) to five (V) can happen to any pregnant woman irrespective of age or number of earlier deliveries. A woman who may have had multiple normal deliveries in the past can experience obstructed labour and be left suffering with an obstetric fistula. Concerning the first point however, which is disparity between the size of the 
mother's pelvis and foetus, where the pelvis of the woman is too small as not to allow normal vaginal delivery to take place, which may be as a result of a number of factors which include:

a. Chronic under nutrition: Studies have shown that under nutrition in childhood leads to small body size in adulthood. The critical periods are intrauterine period, early childhood and adolescence. If there was malnutrition during these periods, it would definitely affect growth in adulthood. Nutrition is really very important in reproduction, including safe delivery. Failure to achieve a normal delivery is directly related to the height of the mother, which is influenced by nutritional status in childhood and adolescence. Evidence shows that the shorter a woman is, the more likely that there would be a significant disproportion between the foetus and the maternal pelvis which results in obstructed labour. Thus, flattening of the pelvis is generally associated with a height $<152 \mathrm{~cm}$.

b. Another factor responsible for poor or distorted pelvic growth is certain infections and diseases, such as rickets in infancy and childhood, and osteomalacia in adolescence and adulthood.

c. It can also occur in subsequent pregnancies where the maternal nutrient deprivation may result in a distorted pelvis, or in women prone to pelvic fractures and other acquired pelvic deformities, (Konje and Ladipo).

Thus, the notion that, early marriage in itself is the major cause of obstructed labour is proven to be untrue. It is not the age that actually causes the obstruction but rather, it is the size of the pelvis where the mother has not achieved her maximal growth potential, which may be as a result of chronic malnutrition which can contribute to the underdevelopment of the woman's physiology and eventually limits the pelvic dimension. Obstructed labour is more prevalent in developing countries where there is abject poverty which leads to lack of proper and balanced diet throughout life, which eventually affects and retards growth. Lack of education which ultimately results in poor uptake of antenatal services which help in detecting risks early enough for precautionary measures to be taken, lack of adequate health care delivery facilities, or other socioeconomic and cultural factors that oppose orthodox antenatal care and delivery are other factors, each of which is capable of causing fistula.

Moreover, teen pregnancy in the west is so rampant nowadays and the rate is always going up. What is interesting however is that, these teenage mothers do not encounter obstruction during labour and delivery. In almost all cases they deliver safely through the normal vaginal delivery. This is because all of the factors that are associated with obstruction such as malnutrition, lack of education, lack of adequate health care delivery facilities, etc are absent in their lives. Even if there are risks to these teenage mothers, the risks are associated more with socioeconomic factors than with biological effects of age, and even these are detected early and necessary medical cautions are promptly taken (wikipedia.org).

\subsection{Treatment}

There are different ways of treating obstetric fistula. However, the two major methods are the transvaginal repair and the abdominal approach. Most obstetric fistulae are amenable to transvaginal repair. Advantages of this approach include a low complication rate, minimal blood loss, rapid past operative recovery and shorter hospital stay. If the fistula is as a result of pelvic surgery, the vaginal approach also avoids re-exploration of the previous operative field. If access is poor and the fistula cannot be brought down, then the abdominal approach should be used. The abdominal approach is when the repair is made through the abdomen, which is more difficult and more complicated than the vaginal approach (Blackwell Synergy: 2006).

\section{Eliminating Obstetric Fistula}

Obstructed labour, which is the major cause of obstetric fistula in the developing countries including some Muslim majority areas, is preventable and by so doing, obstetric fistula could be reduced to the barest minimum or even eliminated completely. This can be done through the following:

I. In cases where a particular girl has not achieved/attained her maximal growth potential, and it becomes clear that she cannot cope/bear the burden of childbearing, the parents should delay the marriage of such girl until the time she is fit enough. After all, even the early marriage is not compulsory but permissible. Even if it is compulsory, and becomes clear that it may endanger the life of the girl, it is not allowed to do it, because Islam is always protecting life. However should the parents insist on marrying up the girl for one reason or the other, may be the girl cannot abstain from illicit relationships, then the couples after the marriage should be advised to delay childbearing.

II. Improving the health and nutrition of children during their rapid growth, starting in utero up to womanhood. Such programmes should be to enhance skeletal growth as well as the general growth and development of the child (mother-tobe). There should also be elimination of infections that commonly affects malnourished children, particularly in early childhood.

III. Provision of adequate and effective health care services, delivery facilities including adequately equipped and staffed ante natal and post natal clinics in the rural areas. There is also the need 
to design and implement an effective health education to the populace on the importance of utilizing ante natal and maternity services especially in rural areas. This is because, through visiting the ante natal clinics complications can easily be detected early enough for necessary intervention.

IV. Counselling and enlightenment unit should be opened in all localities to enlighten people on the subject of obstetric fistula and the need for community participation in helping pregnant women when in need.

V. Since more than $75 \%$ of all deliveries in Nigeria are attended by traditional birth attendants (Kabir et al, 2006), there is the need for the government to train traditional birth attendants.

VI. Policies that encourage formal education of the young women as well as economic empowerment of them should be put in place.

\section{Conclusion and Recommendations}

Looking at all the discussions above, it becomes clear that early marriage on its own is not a cause of obstetric fistula, hence instead of trying to promulgate a law banning early marriage, the most important thing is trying to eliminate obstetric fistula by following all the points raised above and even others that have not been mentioned. And since Islam allows marriage at either majority or minority as it has not fixed a minimum nor maximum age of marriage, an individual should be allowed that right to either marry early or delay it depending on his/her choice and discretion. However, where there is high risk of immorality, it is most preferable that early marriage should be resorted to particularly when there is no envisaged danger. However, if it is clear that there is likelihood of danger as a result of the early marriage, for instance when the girl is too tiny, thus has not achieved her maximal growth potentials, then the marriage should be delayed to save lives. But should the parents/couples insist on the early marriage, then childbearing should be delayed.

\section{References}

\section{Print Sources}

I. Abdal-Ati, H (1982), The Family Structure in Islam, Islamic Publications Bureau, Lagos

II. Abdur-Ra'uf, A.I (2003) Marriage to Minors in Islam: The Truth concerning the Age of A'isha (R.A) at Marriage, Islamic Heritage Foundation

III. Ali, Y, The Holy Qur'an

IV. Arthen, S.C, Rites of Passage: Puberty

V. Campbell, S. et al (2001) Gynaecology by Ten Teachers, Arnold, Hodder Headline, London

VI. Campbell, S, et al, (2001) Obstetrics by Ten Teachers, Arnold Hodder Headline, London

VII. Jones, D.L, (1989) Everywoman, IPL, London

VIII. Khan, M.M, Sahih al Bukhari (English Translation), Hilal Yayinlari, Turkey

IX. Konje, J.C \& Ladipo, O.A, Nutrition and Obstructed Labour (in) The American Journal of Clinical Nutrition

\section{Online sources}

I. Bello, K, A Selection of Essays on VVF-Vesico vaginal Fistula, www.idre.ca visited in November 2006

II. Blackwell synergy vol. 83 pp564-570, Vesico vaginal Fistula, www.emedicine.com/med/3092, visited November, 2006

III. Kabir, M et al, (2006) Medico-Social Problems of Patients with Vesicovaginal Fistula in Murtala Muhammad Hospital, www.forwarduk.org, visited in Nov, 2006

IV. Mohammad, R.H (2013) Vesico vaginal Fistula (VVF) A Problem of Under-development, www.gamji.com/article 5000/NEWS5652.htm

V. fistulacare.org/pages/in-action/stories/prof-azim

VI. fortishospitals.wordpress.com/2010/06/10

VII. en.wikipedia.org/wiki/Teenage_pregnancy

VIII. news.bbc.co.uk/2/hi/uk

IX. www.bladderandbowelfoundation.org/bladder/

X. www.experts123/g/what-causes-obstructed-labour-html

XI. www.gfmer.ch/obstetrics-simplified

XII. www.nursing-help.com/2011/03 